\title{
PENGEMBANGAN MODUL PEMBELAJARAN TEMATIK MELALUI PROBLEM BASED LEARNING
}

\author{
Sobilan Mubarak ${ }^{1}$; Ansharullah ${ }^{2}$; Happy Indira Dewi ${ }^{3}$ \\ SDN Duri Pulo 08 Pagi $^{1}$; Magister Teknologi Pendidikan Fakultas Ilmu Pendidikan, Universitas \\ Muhammadiyah Jakarta ${ }^{23}$ \\ mubaraksobilan@gmail.com; step_ansharullah@yahoo.com; h.indiradewi@umj.ac.id
}

\section{ABSTRACT}

This study aims to develop a PBL-based learning module to increase the HOTS of fourth-grade students at SDN Duri Pulo 08 Pagi in the 2019-2020 school year. The method used in the development of the learning module in this study uses the research and development method (Richey \& Klein) by following the ADDIE development steps. Data analysis in this study used the normality test technique and the average comparison test. The results of this study indicate that the pre-test \& post-test correlation test is 0.936 and the t-count result is 16.760, meaning that the PBL-based module gives good results in the form of the PBL-based module being able to increase and influence the HOTS ability of students.

Keywords: Learning module, PBL, HOTS, Research, and Development, ADDIE

\begin{abstract}
ABSTRAK
Penelitian ini bertujuan untuk mengembangkan modul pembelajaran berbasis PBL dengan tujuan untuk meningkatkan HOTS siswa kelas IV SDN Duri Pulo 08 Pagi tahun pelajaran 2019-2020. Metode yang digunakan dalam pengembangan modul belajar dalam penelitian ini menggunakan metode research and development (Richey \& Klein) dengan mengikuti langkah-langkah pengembangan ADDIE. Analisis data pada penelitian ini menggunakan teknik uji normalitas dan uji perbandingan ratarata. Hasil penelitian ini menunjukkan uji korelasi pre-test \& post-test sebesar 0,936 dan hasil $t$ hitung sebesar 16.760, artinya bahwa modul berbasis PBL memberikan hasil yang bagus berupa modul berbasis PBL mampu meningkatkan dan berpengaruh terhadap kemampuan HOTS pada siswa.
\end{abstract}

Kata kunci: Modul pembelajaran, PBL, HOTS, Research and Development, ADDIE

\section{PENDAHULUAN}

Pendidikan merupakan perkara penting dalam kehidupan manusia, melalui pendidikan kita akan memiliki kecakapan dalam hidup untuk bersaing menghadapi kehidupan yang terus bergerak maju diberbagai bidang. Pendidikan juga pada saat ini seharusnya membentuk siswa yang dapat menghadapi era globalisasi, masalah lingkungan hidup, kemajuan tekhnologi, ekonomi berbasis pengetahuan, kebangkitan industry kreatif, dan budaya, pergeseran kekuatan ekonomi dunia, serta pengaruh dan imbas tekhnologi berbasis sains.

Proses belajar dan mengajar
merupakan dua konsep yang tidak bisa

dipisahkan satu sama lain. Belajar mengajar merupakan proses interaksi antara guru dan siswa pada saat proses pembelajaran. Proses pembelajaran akan berhasil jika ditentukan oleh kemampuan seorang guru dalam menentukan metode dan alat yang digunakan dalam pembelajaran.

Pembelajaran pada umumnya masih menekankan pada aspek pengetahuan dan pemahaman materi saja. Hal ini menyebabkan peserta didik kurang terlatih mengembangkan keterampilan berpikir dalam memecahkan masalah dan menerapkan konsep-konsep yang dipelajari di sekolah ke dalam dunia nyata. Dalam pembelajaran di kelaspun dapat terlihat saat 
diberikan pertanyaan, hanya beberapa peserta didik saja yang menjawab pertanyaan dari guru. Peran serta peserta didik dalam proses pembelajaran masih kurang, yakni hanya sedikit peserta didik yang menunjukkan keaktifan berpendapat dan bertanya.

Pertanyaan yang dibuat peserta didik juga belum menunjukkan pertanyaanpertanyaan kritis berkaitan dengan materi yang dipelajari. Kemudian jawaban dari pertanyaan masih sebatas ingatan dan pemahaman saja, belum terdapat sikap peserta didik yang menunjukkan jawaban analisis terhadap pertanyaan guru. Hal tersebut dikarenakan kurangnya informasi atau penjelasan secara lengkap mengenai bacaan pada materi yang dipelajari oleh peserta didik.

Dalam proses pembelajaran saat ini masih banyak guru atau pendidik yang hanya mengajarkan kepada peserta didiknya hanya dengan melalui buku paket tematik saja, sedangkan dalam pembahasan yang terdapat dalam buku paket pun masih dibilang minim dalam pembahasannya sedangkan dari setiap pembelajaran terdiri dari beberapa mata pelajaran yang digabungkan dalam pembelajaran tematik atau kurikulum 2013 tersebut sehingga pembelajaran masih kurang inovatif dan kreatif sehingga perangkat pembelajaran tersebut dengan bersumberkan pelajarannya hanya mengandalkan dari buku guru, buku siswa dan media pembelajaran seadanya saja, sehingga proses pembelajaran berjalan dengan biasa saja tanpa adanya timbal balik atau respon dari siswa dalam pembelajaran yang lebih menarik maupun lebih serius dalam pemahaman dan wawasan berfikir siswa.
Pelajaran konvensional di kalangan peserta didik kelas IV masih dianggap sebagai produk, yaitu berupa kumpulan konsep yang harus dihapal sehingga berdampak pada rendahnya kemampuan peserta didik pada aspek kognitif. Aspek kognitif terdiri dari enam aspek yakni mengingat, memahami, menerapkan, menganalisis, mengevaluasi dan menciptakan. Namun pada kenyataannya aspek tingkat tinggi seperti analisis mengolah masalah, mengevaluasi, serta menciptakan belum biasa dilatihkan, dan kepada peserta didik masih kesulitan dalam menerapkan pengetahuan yang dimiliki dalam kehidupan sehari- hari.

Peserta didik juga belum biasa menyelesaikan suatu permasalahan yang didahului dengan kegiatan penyelidikan. Jika prinsip penyelesaian masalah ini diterapkan dalam pembelajaran, maka peserta didik dapat terlatih dan membiasakan diri berpikir kritis secara mandiri. Pentingnya penggunaan modul ditunjukkan oleh observasi dari beberapa sekolah yang ada di lingkungan Jakarta Pusat yang berletak di Kecamatan Gambir di Wilayah Binaan II khususnya Kelas IV SD berdasarkan hasil observasi masih banyak sekolah yang belum memanfaatkan bahan ajar secara maksimal dan sesuai.

\footnotetext{
Kemendikbud menyatakan bahwa salah satu model pembelajaran yang ditekankan pada Kurikulum 2013 ini adalah penggunaan model pembelajaran Problem Based Learning (PBL) (Kemendikbud, 2015). Pembelajaran PBL merupakan suatu model pembelajaran yang berbasis masalah sebagai hal yang muncul pertama kali pada
} 
saat proses pembelajaran (Abidin, 2016). Sesuai dengan masalah yang terjadi pada proses pembelajaran di kelas, penggunaan PBL ingin mengubah kondisi belajar yang pasif menjadi aktif dan kreatif dengan cara mengubah proses pembelajaran yang awalnya teacher oriented menjadi student oriented.

Penelitian yang dilakukan Bakhri dan Supriadi tentang peran PBL dalam upaya peningkatan HOTS siswa pada pembelajaran matematika menyatakan bahwa PBL memberikan pengaruh yang signifikan terhadap kemampuan pemecahan masalah terutama terkait dengan HOTS. PBL menjadi salah satu strategi pembelajaran yang bisa meningkatkan HOTS siswa (Bakhri \& Supriadi, 2017).

HOTS merupakan suatu proses berpikir anak didik dalam level kognitif yang lebih tinggi yang dikembangkan dari berbagai konsep dan metode kognitif dan taksnonomi pembelajaran (Saputra, 2016). Keterampilan berpikir sangat mendasar dalam proses pendidikan.

Pemikiran seseorang bisa mempengaruhi kemampuan, kecepatan dan efektivitas belajar. Oleh karena itu, kemampuan dalam berpikir sangat terkait dengan proses belajar siswa yang dilatih untuk berfikir HOTS menunjukkan dampak positif pada pengembangan pembelajarannya. Siswa dengan HOTS dapat belajar meningkatkan kinerjanya dan menguranginya kelemahan mereka (Heong et al., 2011).

Budsankom et al., menyatakan bahwa siswa yang memiliki HOTS mampu menciptakan pengetahuan yang baru dan membuat keputusan yang logis. HOTS merupakan suatu proses berfikir anak didik dalam level kognitif yang lebih tinggi, yang bertujuan untuk meningkatkan kemampuan berfikir kritis, berfikir kreatif, mampu menyelesaikan masalah dan mampu membuat keputusan dalam situasi yang sulit (Budsankom et al., 2015).

Berdasarkan berbagai uraian di atas, maka timbul gagasan peneliti untuk mengembangkan modul pembelajaran tematik kurikulum 2013 melalui PBL dengan bertujuan untuk meningkatkan HOTS pada pembelajaran. Modul pembelajaran ini nantinya akan dikembangkan berdasarkan konsep pengembangan model $A D D I E$.

\section{KAJIAN LITERATUR \\ - MODUL PEMBELAJARAN}

Branch mengemukakan Modul merupakan paket intruksional dengan satu tema terpadu yang menyediakan informasi yang dibutuhkan untuk mengembangkan penguasaan pengetahuan dan keterampilan tertentu, dan berfungsi sebagai salah satu komponen dari total kursus atau kurikulum (Branch, 2014).

Modul dapat dirumuskan sebagai unit lengkap yang berdiri sendiri dan terdiri atas suatu rangkaian kegiatan belajar yang disusun untuk membantu peserta didik dalam mencapai tujuan yang dirumuskan secara khusus dan jelas (Sani, 2013).

Menurut Nurdin sistem pembelajaran menggunakan modul menitik beratkan pada aktivitas siswa dan kreativitasnya dalam proses pembelajaran dan menerapkan pembelajaran maju dan berkelanjutan (Nurdin \& Adriantoni, 2016). Asyar mendifinisikan bahwa modul merupakan 
bahan ajar yang dirancang untuk belajar mandiri (Asyhar, 2012). Pendapat tersebut didukung oleh Daryanto yang menyatakan bahwa modul merupakan salah satu bahan ajar yang disusun secara sistematis, yang didalamnya teridiri dari seperangkat pembelajaran yang terencana dan di desain untuk membantu peserta didik dalam mencapai tujuan pembelajaran (Daryanto, 2014).

\section{- PEMBELAJARAN TEMATIK}

Abdul Majid dalam Konsep dasar pembelajaran tematik menjelaskan bahwa Pembelajaran Tematik adalah pembelajaran terpadu yang menggunakan tema untuk mengaitkan beberapa mata pelajaran dari mulai mata pelajaran satu dengan lainnya, sehingga dapat memberikan pengalaman bermakna kepada siswa (Majid, 2014). Sejalan dengan pendapat Rusman, Mamat S.B., dkk (Mamat et al., 2005)memaknai pembelajaran tematik sebagai pembelajaran terpadu, dengan mengelola pembelajaran yang mengintegrasikan materi dari beberapa mata pelajaran dalam satu topik pembicaraan yaitu tema.

Pendapat tersebut dilengkapi oleh Andi Prastowo dalam Pengembangan Bahan Ajar Tematik bahwa pembelajaran tematik integratif merupakan pendekatan pembelajaran yang menyatukan berbagai kompetensi dari beberapa mata pelajaran ke dalam berbagai tema. pengintegrasian tersebut dilakukan melalui pendekatan intradisipliner, multi disipliner, interdisipliner, dan transdisipliner (Prastowo, 2011).

Pembelajaran tematik merupakan salah satu model pembelajaran terpadu (integrated instruction) yang merupakan suatu sistem pembelajaran yang memungkinkan siswa, baik secara individu maupun kelompok aktif dalam menggali dan menemukan konsep serta prinsip prinsip keilmuan secara holistik, bermakna, dan otentik. Dari penjelasan di atas dapat di deskripsikan bahwa pembelajaran tematik adalah pembelajaran yang dirancang berdasarkan tema-tema sebagai salah satu model pembelajaran terpadu (integrated instruction) yaitu mengaitkan beberapa aspek baik dalam intra mata pelajaran maupun antar-mata pelajaran yang merupakan suatu sistem pembelajaran sehingga memungkinkan siswa, baik secara individu maupun kelompok aktif.

\section{- PBL (PROBLEM BASED LEARNING)}

Metode Problem Based Learning atau yang dikenal dengan Pembelajaran Berbasis Maslah merupakan sebuah metode pembelajaran yang menyjikan masalah kontekstual sehingga merangsang siswa untuk belajar. Di dalam kelas yang menerapkan metode Problem Based Learning, siswa bekerja dalam tim untuk memecahkan masalah dalam kehidupan nyata.

Tan dalam Rusman menyatakan bahwa, Metode Problem Based Learning merupakan inovasi dalam pembelajaran karena dalam metode pembelajarn ini kemampuan berfikir siswa dioptimalisasikan melalui proses kerja kelompok atau tim yang sistematis, sehingga siswa dapat memberdayakan, mengasah, menguji, dan mengembangkan kemampuan berfikir secara berkesinambungan kelompok orang, atau lingkungan untuk memecahkan masalah yang 
bermakna, relevan, dan kontekstual (Rusman, 2013).

Sedangkan menurut Trianto berpendapat bahwa metode Problem Based Learnig merupakan suatu metode pembelajaran yang didasarkan pada banyaknya permasalahan yang membutuhkan penyelidikan authentic yakni penyelidikan yang membutuhkan penyelesaian nyata dari permasalahan yang nyata (Trianto, 2010).

\section{- HIGH ORDER THINKING SKILL (HOTS)}

HOTS adalah taksonomi bloom, pemikiran ini didasarkan dari beberapa jenis pembelajaran memerlukan proses kognitif yang lebih dari pada yang lain, tetapi mempunyai manfaat lebih. Pada taksonomi bloom HOTS sebagai contoh melibatkan kemampuan untuk menganalisis, mengevaluasi dan mencipt (Pohl, 2000). Menurut Engelhart dkk, indikator untuk mengukur HOTS diantaranya meliputi:1) Menganalisis, yaitu siswa dapat menganalisis informasi yang masuk dan menstrukturkan informasi kedalam bagian yang lebih kecil untuk mengenali sebuah pola atau hubungan. Selain itu, siswa mampu mengenali serta membedakan faktor penyebab dan akibat dari sebuah skenario dan mampu mengidenifikasi dan merumuskan pertanyaan, 2) Mengevaluasi, yaitu siswa mampu memberikan penilian terhadap solusi, gagasan dan metodologi dengan menggunakan kriteria yang cocok atau standar. Selain itu siswa mampu mengkritik, membuat hipotesis dan melakukan pengujian dan mampu menerima atau menolak suatu pernyataan sesuai dengan kriteria yang telah diciptakan, 3) Mencipta, yaitu siswa mampu membuat generalisasi suatu ide atau cara pandang terhadap sesuatu. Siswa juga mampu merancang suatu cara untuk menyelesaikan masalah dan mampu mengorganisakan unsur-unsur menjadi struktur baru (Engelhart et al., 1956).

Pada penjelasan diatas terdapat disintesa bahwa HOTS terdiri dari kemampuan menganalisis, mengevaluasi dan akhirnya akan menciptakan produk/karya yang inovatif. Ketiga kemampuan pada HOTS ini hendaknya ditingkatkan melalui pembelajaran tematik dengan menggunakan modul yang kembangkan melalui PBL.

\section{METODE PENELITIAN}

Penelitian dilaksanakan di SDN Duri Pulo 08 Pagi. Penelitian dilakukan pada semester genap tahun ajaran 2020/2021 yaitu pada bulan Januari. Populasi dalam penelitian ini adalah siswa kelas IV SDN Duri Pulo 08 Pagi. Penelitian ini merupakan penelitian pengembangan dengan menggunakaan ADDIE dan pendekatan penelitian ini berbasis PBL. Pendekatan ini digunakan masalah disajikan pada awal pembelajaran dilakukan dan siswa diarahkan untuk menyelesaikan masalah yang ada. Pengumpulan data dalam penelitian ini menggunakan modul pembelajaran dan angket.

Langkah-langkah pengembangan model dalam penelitian ini dengan cara 1) peneliti melakukan observasi dan mengumpulkan data-data terkait dengan penerapan model pembelajran di sekolah kecamatan Gambir wilayah Binaan II, 2) analisis kebutuhan dengan cara pengembangan modul melalui angket dan wawancara yang dibagikan kepada guru, 3) 
perancangan pengembangan modul berdasarkan langkah ADDIE, 4) validasi, evaluasi \& revisi, 5) implementasi modul dengan menggunakan teknik pengumpulan data melalui memberikan perlakuan terhadap subjek yang akan diteliti melalui pretest dan posttest dan analisis data menggunakan teknik uji normalitas dan uji perbandingan rata-rata.

\section{PEMBAHASAN}

Berdasarkan hasil pengembangan modul terdapat hasil analisis kebutuhan dengan melakukan observasi di sekolah yang menunjukkan bahwa Modul buku tematik kurikulum 2013 belum lengkap dan sesuai dengan kondisi/kebutuhan siswa serta perlu dilakukan penyesuaian dan pengembangan sesuai kondisi/kebutuhan siswa. Oleh karena itu peneliti melakukan pengembangan modul dengan cara menambahkan bentuk soal latihan pada setiap akhir sub tema.

\section{- KELAYAKAN MODUL (TEORITIK DAN EMPIRIS)}

Berdasarkan kelayakan modul dengan menggunakan penyebaran angket, terdapat hasil 1) uji kelayakan media yang dilakukan oleh ahli media menunjukkan bahwa rata-rata dari hasil modul yaitu $87,96 \%$ yang berarti modul tersebut berada pada interpretasi hasil yang sangat layak dan terdapat juga beberapa saran yang diberikan masukkan dari ahli media tersebut yaitu : perlu ditambahkan lagi tampilan-tampilan atau gambar dan variasi yang lebih menarik lagi pada modul tersebut, 2) uji kelayakan materi yang dilakukan oleh ahli materi menunjukkan bahwa rata-rata modul $90,45 \%$ yang berarti modul tersebut berada pada hasil yang sangat layak, terdapat beberapa saran atau masukkan dari ahli dan saran dari ahli tersebut digunakan sebagai acuan untuk merevisi materi pada modul yang dikembangkan, 3) uji coba kelompok kecil dilakukan oleh 5 orang siswa yang dipilih secara acak menunjukkan bahwa modul berbasis PBL yang dikembangkan oleh peneliti memiliki interpretasi atau hasil yang sangat baik dari hasil uji validasi dan uji coba menunjukkan bahwa modul tersebut yang berbasis PBL layak untuk digunakan atau diterapkan sebagai bahan ajar pada uji coba lapangan pada sekolah, 4) uji coba kelompok besar dilakukan oleh 31 orang siswa menunjukkan bahwa nilai rata-rata dari keseluruhan aspek yaitu $84 \%$ dan hal ini menunjukkan bahwa modul yang dikembangkan tersebut memiliki hasil dan manfaat yang sangat baik.

\section{Sebelum:}

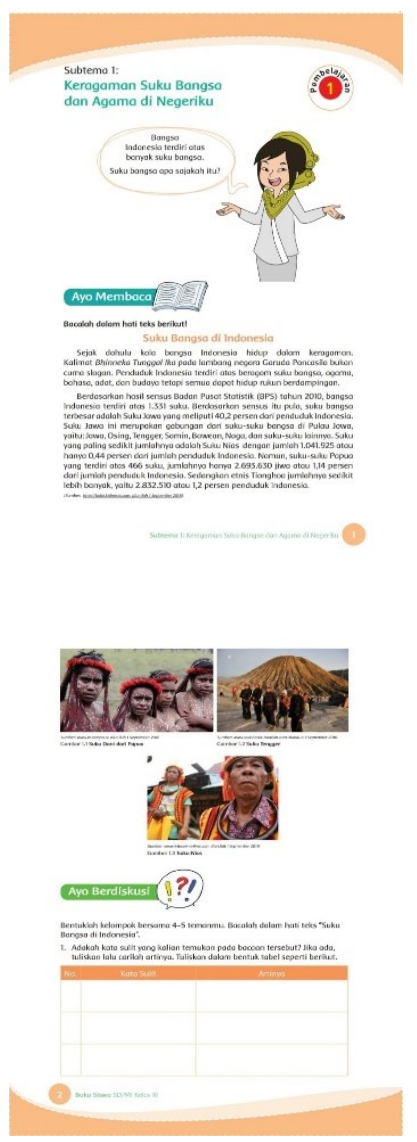




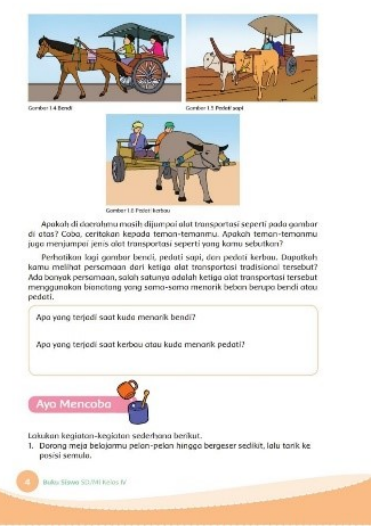

Gambar 1 Modul sebelum dimodifikasi

\section{Sesudah:}

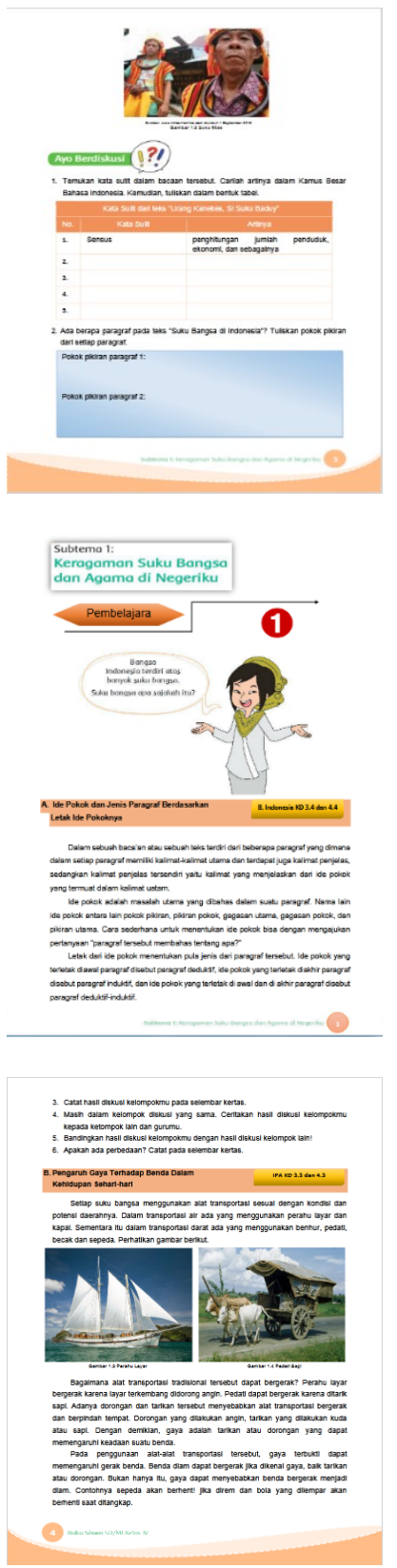

Gambar 2 Modul sesudah dimodifikasi

- $\quad$ EFEKTIVITAS (MELALUI UJI COBA)

MODUL

Berdasarkan efektivitas modul (melalui uji coba) dengan menggunakan metode pretest dan posttest, terdapat hasil sebagai berikut 1) uji normalitas menggunakan Shapiro-wilk menunjukkan hasil nilai signifikasi Variabel Sesudah 0,091 yang berarti lebih besar dari probabilitas 0,05 dan nilai signifikasi variabel Sebelum 0,000 yang berarti kurang dari probabilitas 0,05 artinya perlakuan sesudah menunjukkan distribusi normal, sedangkan perlakuan sebelum menunjukkan tidak berdistribusi normal, 2) uji perbandingan rata-rata menggunakan metode paired sample t-test menunjukkan hasil bahwa sebelum perlakuan menggunakan modul, nilai rata-rata siswa/i adalah 69,71 dan sesudah menggunakan modul nilai rata-rata siswa/i adalah $77,06,3$ ) uji korelasi menggunakan metode paired samples correlations menunjukkan hasil korelasi antara dua sampel ditunjukkan dengan angka 0,936 dengan angka probabilitas 0,000 di bawah 0,05 berarti bahwa hubungan antara sebelum dan sesudah menggunakan modul adalah nyata dan sangat erat, 4) hasil uji t menunjukkan bahwa Sig.(2tailed) $=0,000$. hal itu berarti probabilitas kurang dari 0,05 yang berarti juga bahwa Ho ditolak. Hal ini di peroleh dengan dasar pengambilan keputusan bahwa ada perbedaan rata-rata antara hasil belajar pretest dan posttest yang artinya ada pengaruh penggunaan modul dalam meningkatkan hasil belajar siswa. Selain itu, peneliti juga melihat perbandingan nilai $\mathrm{t}$ hitung dan $t$ tabel dengan menunjukkan hasil $\mathrm{t}$ hitung $16.760>\mathrm{t}$ tabel -1.607 , maka 
sebagaimana dasar pengambilan keputusan di atas dapat disimpulkan bahwa ada perbedaan rata-rata antara hasil belajar pretest dan posttest yang artinya ada pengaruh penggunaan modul dalam meningkatkan hasil belajar siswa

Tabel 1. Hasil Uji-T Hasil Belajar Pretest dan Posttest

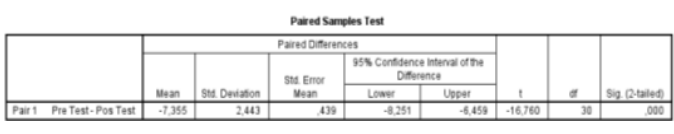

\section{PENUTUP}

Berdasarkan pengembangan Modul Pembelajaran Tematik melalui Problem Based Learning dan pembahasn hasil penelitian yang telah dibahas pada bab sebelumnya, maka dapat disimpulkan sebagai berikut 1) penelitian yang dilakukan merupakan penelitian pengembangan dengan dilakukan melalui lima tahap pengembangan ADDIE. Tahapan pengembangan ADDIE dalam penelitian ini meliputi tahap analysis (analisis), tahapan design (desain) merancang modul yang akan dikembangkan, tahapan develop (pengembangan) membuat modul berbasis PBL dan membuat soal untuk mengukur HOTS, tahapan implement (implementasi) validasi produk ke ahli media serta ahli materi dan tahapan evaluate (evaluasi) uji coba pemahaman dengan soal HOTS, 2) penelitian yang dilakukan menghasilkan produk berupa modul pembelajaran tematik berbasis PBL dengan bertujuan untuk meningkatkan HOTS siswa pada pembelajaran tematik kurikulum 2013, 3) kualitas produk termasuk kriteria "sangat layak" dengan rata-rata persentase $87,96 \%$ dari hasil validasi oleh ahli media. Menurut uji kelayakan materi kualitas modul "sangat layak" dengan persentase 90,45\%.
Sedangkan penilaian uji coba kelompok kecil dengan 5 orang siswa menyatakan bahwa modul tematik yang berbasis PBL "sangat layak" persentase $89,88 \%$ dan uji coba kelompok besar dengan 31 orang siswa menyatakan bahwa modul yang dikembangka tersebut memiliki hasil dan manfaat yang "sangat layak" dengan persentase 90,13\%, 4) modul berbasis PBL yang telah dikembangkan mampu meningkatkan HOTS pada siswa. Berdasarkan hasil uji coba lapangan terhadap modul yang dikembangkan terdapat peningkatan hasil nilai pretest dan posttest pada siswa.

\section{REFERENSI}

Abidin, Y. (2016). Desain Model Pembelajaran dalam Konteks Kurikulum 2013. PT Refika Aditama.

Asyhar, R. (2012). Kreatif Mengembangkan Media. Gaung Persada Press.

Bakhri, S., \& Supriadi. (2017). Peran ProblemBased Learning (PBL) dalam Upaya Peningkatan Higher Order Thinking Skills (HOTS) Siswa pada Pembelajaran Matematika. Seminar Matematika Dan Pendidikan Matematika Uny, 717-722.

Branch, R. M. (2014). Instructional Design: The ADDIE Approach. Springer US.

Budsankom, P., Sawangboon, T., Damrongpanit, S., \& Chuensirimongkol, J. (2015). Educational Research and Reviews Factors affecting higher order thinking skills of students: A meta-analytic structural equation modeling study. 10(19), 2639-2652. https://doi.org/10.5897/ERR2015

Daryanto. (2014). Menyusun Modul: bahan untuk persiapan dalam mengajar. Gava Media. 
Engelhart, M. D., Furst, E. J., \& Krathwohl, D. R. (1956). TAXONOMY OF EDUCATIONAL OBJECTIVES The C.lassiiication of Educational Goals HANDBOOK 1 COGNITIVE DOMAIN.

Heong, Y. M., Othman, W. B., Yunos, J. B. M., Kiong, T. T., Hassan, R. Bin, \& Mohamad, M. M. B. (2011). The Level of Marzano Higher Order Thinking Skillsamong Technical Education Students. International Journal of Social Science and Humanity, 121-125.

https://doi.org/10.7763/ijssh.2011.v1.20

Kemendikbud. (2015). Materi Pelatihan Guru Implementasi Kurikulum 2013 Tahun 2015 Sekolah Dasar Luar Biasa.

Majid, A. (2014). Pembelajaran Tematik Terpadu. PT Remaja Rosdakarya.

Mamat, S., Munir, A., Suwendi, Akar, A. T., \& Asro, H. (2005). Pedoman Pelaksanaan Pembelajaran Tematik. Departemen Agama RI.

Nurdin, S., \& Adriantoni. (2016). Kurikulum dan pembelajaran. Rajawali Press.
Pohl, M. (2000). Learning to Think, Thinking to Learn: Models and Strategies to Develop a Classroom Culture of Thinking. 98.

Prastowo, A. (2011). Panduan kreatif membuat bahan ajar inovatif. Yogyakarta: DIVA press.

Rusman. (2013). Model Pembelajaran Mengembangkan Profesionalisme Guru, Model Pembelajaran Mengembangkan Profesionalisme Guru. Rajawali Pers.

Sani, R. A. (2013). Inovasi pembelajaran.

Saputra, H. (2016). Pengembangan Mutu Pendidikan Menuju Era Global: Penguatan Mutu Pembelajaran dengan Penerapan HOTS (High Order Thinking Skills). In SMILE's Publishing (Vol. 1). Smile's Indonesia Instutite.

Suradika, Agus. (2000). Metode Penelitian Sosial. Jakarta: UMJ Press.

Trianto. (2010). Model pembelajaran terpadu: konsep, strategi, dan implementasinya dalam kurikulum tingkat satuan pendidikan (KTSP). Bumi Aksara. 